\title{
A Study on Products and Services of HCL Technologies
}

\author{
Sudharshan Prabhu S. ${ }^{1}$ \& Vaikunth Pai T. ${ }^{2}$ \\ ${ }^{1}$ II Year MCA, College of Computer \& Information Sciences, Srinivas University, \\ Mangalore, Karnataka, India. \\ ${ }^{2}$ College of Computer \& Information Sciences, Srinivas University, Mangalore, India \\ E-Mail:sudharshansprabhu@outlook.com
}

Type of the Paper: Case Study.

Type of Review: Peer Reviewed.

Indexed In: OpenAIRE.

DOI: http://dx.doi.org/10.5281/zenodo.1253722.

Google Scholar Citation: $\underline{\text { IJCSBE }}$

\section{How to Cite this Paper:}

Sudharshan Prabhu, S. \& Vaikunth Pai T. (2018). A Study on Products and Services of HCL Technologies. International Journal of Case Studies in Business, IT and Education (IJCSBE), 2(1), 45-53. DOI: http://dx.doi.org/10.5281/zenodo.1253722.

International Journal of Case Studies in Business, IT and Education (IJCSBE)

A Refereed International Journal of Srinivas University, India.

(C) With Authors.

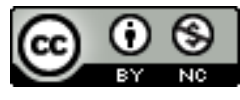

This work is licensed under a Creative Commons Attribution-Non Commercial 4.0 International License subject to proper citation to the publication source of the work.

Disclaimer: The scholarly papers as reviewed and published by the Srinivas Publications (S.P.), India are the views and opinions of their respective authors and are not the views or opinions of the S.P. The S.P. disclaims of any harm or loss caused due to the published content to any party. 


\title{
A Study on Products and Services of HCL Technologies
}

\author{
Sudharshan Prabhu S. ${ }^{1}$ \& Vaikunth Pai T. ${ }^{2}$ \\ ${ }^{1}$ II Year MCA, College of Computer \& Information Sciences, Srinivas University, \\ Mangalore, Karnataka, India. \\ ${ }^{2}$ College of Computer \& Information Sciences, Srinivas University, Mangalore, India \\ E-Mail:sudharshansprabhu@outlook.com
}

\begin{abstract}
HCL Technologies Ltd. is an IT Software, service, and consulting company, headquartered at Noida, Uttar Pradesh, India. It is the part of HCL Enterprises Company. In 1976, a group of six engineers started a company that would make personal computers and the group was led by Mr. Shiv Nadar. Initially, the company name was Micro Comp Ltd. The company started to sell tile digital calculators to gather capital for their main project. On 11 August 1976, the company was renamed to Hindustan Computer Limited (HCL). On 12th November 1991, another subsidiary company called HCL Overseas Limited was incorporated as a provider of technology development service. HCL company is one of the four companies comes under the company HCL enterprises. HCL developed an indigenous microcomputer in 1978, and a networking OS and client-server architecture in 1983. On 12 November 1991, HCL Technologies was distributed as a separate unit to provide software services. Hindustan Computer Limited offers services including IT Consulting, Enterprise Transformation, remote infrastructure management, engineering and $R \& D$, and business process outsourcing (BPO). HCL services include DRYiCE, Cybersecurity, and digital \& analytics. The company has the branches in 34 countries including USA, CANADA, JAPAN, UK, FRANCE, and GERMANY. It operates across sectors including aerospace and defense, automotive, consumer electronics energy and utilities, financial service and governments. HCL Technologies in Forbes Global 2000 list. As of September 2017, the company along with its subsidiaries had consolidated revenue of $\$ 7.4$ billion. In this paper, we have studied the products and services of HCL technologies and its strategies to face competitions using various case study methodologies. The internal and external opportunities analysis is done by means of SWOT analysis.
\end{abstract}

Keywords: Micro Comp Ltd., R\&D Division, DRYiCE, Business Process Outsourcing, Forbes Global List.

\section{INTRODUCTION :}

Company analysis is an important type of case method in Research Methodology and is usually considered by the beginners of scholarly research. Out of two models of studying a company, the first model is on studying its business in terms of its products and services. This also involves studying various functions of the company which involves its productivity and sustainability. The second model is related to how the managers handle the situations and make decisions to solve the company problems to realize its objectives. A systematic study and procedure are developed for company analysis and available for reference [1-10]. Many analysis frameworks are used in different company case studies to study internal aspects of a company which includes ABCD analysis, SWOC analysis etc [11-19]. This paper involves the study of products and services of HCL technologies and its strategies to face competitions using various case study methodologies [20-26]. The internal and external opportunities analysis is done by means of SWOT analysis [17-19].

HCL (Hindustan Computer Limited) is an Indian Multi-National Information Technology Service Company. The head quarter of HCL Company is located at Noida, Uttar Pradesh, India. HCL is collateral of HCL Enterprises. It handles the research and development part of the HCL Enterprises 
[27-28 2]. HCL also provides services such as DRYiCE, Cyber security and Digital \& Analytics. HCL Technologies ltd. IT Software, service, and consulting company, headquartered in Noida, Uttar Pradesh, India. It is the part of HCL Enterprises Company. In 1976, a group of six engineers started a company that would make personal computers and the group was led by Shiv Nadar. Initially the company name was Micro Comp Ltd. The company started to sell tile digital calculators to gather capital for their main project. On 11 August 1976 the company was renamed to Hindustan Computer Limited (HCL). On 12 November 1991, another subsidiary company called HCL overseas limited was incorporated as a provider of technology development service. Today, the HCL enterprise has a presence across varied sectors that include technology, healthcare and talent management solutions and comprises three companies - HCL Info systems, HCL Technologies and HCL Healthcare. The enterprise generates annual revenues of over US \$7.5 billion with more than 120,000 employees from 140 nationalities operating across 39 countries, including over 500 points of presence in India.

\section{OBJECTIVES :}

* To understand the type of products and services provided by the company.

* To analyze the overall growth of the company.

* To find the different initiative that will help in environmental sustainability.

* To understand the HR training strategies and corporate social responsibilities of the company.

* To find the competitors of HCL.

\section{ABOUT HCL TECHNOLOGIES :}

The HCL journey has been relentless, gratifying and marked with a series of achievements. Our unified efforts have catapulted the company from a garage start-up to a conglomerate whose businesses span across three verticals. HCL is starts by the long journey they have made so far and at the same time, is confident of raging forward and scaling greater heights. Over the years, HCL has conscientiously set high business standards by way of providing sustainable, world-class products, solutions and services; a feat that has helped the organization to touch the lives of millions with possibilities. Today, the HCL enterprise has a presence across varied sectors that include technology, healthcare and talent management solutions and comprises three companies - HCL Info systems, HCL Technologies and HCL Healthcare. HCL Technologies is a next-generation global technology company that helps enterprises reimaging their businesses for the digital age. Our technology products, services and engineering are built on four decades of innovation, with a world-renowned management philosophy, a strong culture of invention and risk-taking, and a relentless focus on customer relationships. With a worldwide network of R\&D, innovation labs and delivery centres, and $120,000+$ 'Ideapreneurs' working in 39 countries, HCL serves leading enterprises across key industries, including 250 of the Fortune 500 and 650 of the Global 2000. HCL generated consolidated revenues of USD 7.8 billion for 12 months ended 31st March 2018 [27-28].

\section{SMART PRODUCTS AND SERVICES :}

IT Infrastructure: HCL's IT foundation administration administrations have probably the most amazing accreditations in the IT merchant scene. We have additionally been acclaimed for our demonstrated reputation of fruitful, high-intricacy conveyance, consumer loyalty, and inventive arrangements. HCL's IT framework administration administrations offer the experience, ability, and apparatuses required to enable you to make, run and oversee cutting edge IT foundation [29-34].

Application Service: With HCL, you get a new viewpoint and a novel ability. Our conveyance show coordinates nearby business change counselling administrations with close and seaward specialized advancement and support to ensure our customers get the perfect frameworks incorporation arrangements at the correct cost. Business and IT change is a consequence of our exceptional capacities to consolidate our on location and seaward abilities flawlessly [33].

Engineering and R\&D Service: During a time where most corporate speculations have been commoditized, 21st century innovation is tied in with utilizing item and administration innovative work in business to make client driven arrangements through lithe and proficient building. The champs in this new the truth are a type of organizations that take a gander at their organizations with an esteem chain approach - crosswise over client esteem chain, resource esteem chain and 
administration esteem chain. These are the 21st century endeavours - making, receiving and utilizing the approach of advancements past the self-evident! [32].

Engineering Delivery Excellence: A key segment of our example of overcoming adversity has been our capacity to surpass our clients' assumptions about how designing administrations are conveyed. With more than three many years of centre item building knowledge as a designing outsourcing pioneer, today, we can execute building engagements of all scales and complexities with world class efficiencies. Ideal from speedy learning exchange, foundation set-up, group increase to meeting our clients' stringent necessities for amazing conveyance, on-time execution, easy to understand involvement and plan, productive tasks and world-class advancement - this is industrialized conveyance taking care of business.

Business Service: e 21st Century Endeavour is continually developing, and expects administrations that are genuinely client arranged, encounter driven, and conveyed in a really lithe way, customized to guarantee the correct business results. Conventional plans of action extremely limit a venture's capacity to adjust rapidly. With the end goal for associations to better deal with these vulnerabilities, and convey economical execution to succeed and flourish, key changes are basic [31].

Cyber Security and GRC Services: Strategy, Architecture \& Consulting Services

- Architecture Services

- Assessment Services

- Compliance \& Risk Assessment services

- Business Impact Analysis

- Project / Program Management [30]

Cloud Service: HCL offers decision to our clients. We can give an entire Oversaw Cloud as an Administration (McCaa's) putting forth, joining SAP programming, cloud framework, and oversaw benefits in an unadulterated OpEx spending membership. Or on the other hand, as a Gold SAP Accomplice Edge accomplice, HCL can offer SAP Distributed computing Administrations with HCL usage, improvement and administrations wrapped around them. We have expertise delivering solutions in the following areas:

- Strategic HR - HR industry-focused best practices, effective HR organizations, HR transformation roadmap development, competency model development, KPI development, executive reporting, key performance indicator analysis, in-house / outsourced payroll, and business case development.

- Organization - HR business partners, shared services (global, regional local), centres of expertise, centralized HR and de-centralized HR.

- Process - Best practice process outline and execution - workforce organization, workforce administration (counting complex booking), global versatility, time catch, workforce arranging, asset arranging, finance, costs, travel administration, word related wellbeing and security, ability administration (enrolment, execution administration, pay, learning administration, vocation and progression arranging), contact and case administration.

- Technology - Implementation of the software package that best suits the needs of your organization. We have integrated our capabilities in SAP HCM and Success Factors solutions with many major ERP's and 3rd party solutions, such as ADP, Kronos, Nakisha, I Grasp, Cezanne, Aspen and many others. We can improve the picked arrangements; including giving self-benefit capacities to better empower the acknowledgment of advantages.

DRYiCE: DRYiCE Autonomics and Coordination benefit is a suite of administrations, items and stages that use the world's best A.I. innovation, IT computerization, and mechanical process mechanization to empower endeavours to work more slender, speedier, and less expensive, while guaranteeing unrivalled business results. DRYiCE will be the A.I. foundation for the $2^{\text {1st }}$ Century Enterprise [29].

\section{ENVIRONMENTAL SUSTAINABILITY THROUGH GREEN STRATEGY :}

The five elements of nature form the very basis of creation. Earth, Fire, Water, Wind and Atmosphere sustain all forms of life on this planet, working in tandem to give us life as we know it. As organizations and individuals, we can make conscious efforts to respect their influence and make 
responsible investments and actions in ensuring our sustenance. What can businesses do to grow without compromising the ecosystem we live in?

The 'Atmosphere' envelopes all, supportive and enduring in its presence, like the overall organization. We are a Responsible Business that values ethics, strong governance and run the day to day operations based on our core philosophy- Employees First, Customer Second (EFCS) [38].

'Fire', warm and bright, kindling ambitions and illuminating the environment, represents the 'inner fire' that burns brightly in every one of our employees, representing their desire to create and lead change. We strive to continuously redefine the Workplace that facilitates transformational actions led by employees and embraced by the management.

'Earth', diverse and nurturing, sharing with us glorious bounty that we must pass on to future generations, reminds us that we have a duty to renew our Ecosystem.

'Wind', inspiring and unfettered, characterizes change. It cannot be seen but its influence can be felt. Purity of the spirit and heart, clarity of thought within the mind and focused intent are all characteristics of this element. This element represents the commitment our employees have to Repay Society as gentle winds of change.

'Water', flowing and persevering, signifies how we innovate along this transformational journey and break barriers.

HCL has established a framework to tackle the environmental impacts of the Company operations like carbon emissions; water use, waste generated, and materials procured and consumed, impact on biodiversity, travel, and transport in the context of supporting and enhancing in the company activities. This strategy has been developed in consultation with the employees working on the company and other staff and represents a framework for action to be taken.

\section{HR TRAINING AND TRAINING STRATEGY :}

Given the ever-increasing demand for quality talent within HCL, there is a significant need to create a talent pool that will be equipped with the requisite expertise, and be technically and professionally prepared to join the highly specialized workforce at HCL. Enrolment specialists have noticed that the expertise hole crosswise over ventures is essentially an instruction issue - one that makes a confound between what gets educated desiring understudies in establishments, and the desires anticipating them in the genuine activity condition. HCL TSS (HCL Preparing and Staffing Administrations) makes the truly necessary extension between meriting ability the nation over and empty occupations that are hard to fill because of an emergency of aptitudes [39].

\section{CORPORATE SOCIAL RESPONSIBILITY :}

\section{Community initiatives:}

$>$ Project Samudhay, which includes embracing 100 towns and driving change in five regions - water, ladies' welfare, instruction, wellbeing and ailing health, and sanitation. Association with Udayan Gharand over 55 other NGOs, to promote all-round community development and growth [35].

\section{Environment initiatives:}

$>$ HCL runs a multi-layered program Go Green as a piece of its proceeded with manageability activities [35].

\section{ANALYSIS :}

Performance of the Company: HCL Technologies, India's fourth largest IT services firm, claims to have concluded the fourth quarter (Q4) and the last fiscal with an "industry-leading performance" backed by broad-based growth across verticals and robust client additions.

The firm's total income grew around 2 per cent to Rs 13,480 crore in the March 2018 quarter, up from Rs 13,183 crore in the year-ago period. The company's investor release added a significant milestone its annual revenues in the last fiscal crossed Rs 50,000 crores, up 8.2 per cent year-on-year.

Business Overview: HCL Technologies Limited is engaged in providing a range of software development services, business process outsourcing services and information technology (IT) infrastructure services. The Company's segments include software services, infrastructure 
management services and business process outsourcing services. The software services segment provides application development and maintenance, enterprise application, software as a service (SAAS) application services and engineering, and research and development (R\&D) services to global customers. The infrastructure management services segment involves managing customer's IT assets. The business process outsourcing services segment includes contact center and help desk services. The Company delivers its solutions across select verticals, including financial services, manufacturing, retail and consumer products, media, publishing and entertainment, public services, energy and utility, healthcare, and travel, transport and logistics.

\section{Strengths:}

1. Association with Major Brands

2. Consistent revenue growth

3. Acquisition of Axon enables company to offer full SAP services

4. Global Coverage in countries like U.S, Europe, Japan etc.

5. Offers services like ERS, ETS, BPO and EAS

Weakness:

1. Total asset turnover is one of the weaknesses

2. Tough competition from existing PC and laptop brands means limited market share

\section{Opportunity:}

1. New Outsourcing deals

2. Strong presence in defence space and potential to benefit from offset provision in Indian defence imports.

\section{Threats:}

1. Adverse impact of foreign exchange movement

2. Emergence of potentially disruptive technologies/practices like cloud Computing [36].

\section{COMPETITORS :}

- Wipro is a top competitor of HCL Technologies. Wipro was founded in 1945, and is headquartered in Bangalore, Karnataka. Like HCL Technologies, Wipro also competes in the IT Services field. Wipro generates \$1.7B more revenue vs. HCL Technologies.

- CTS is seen as one of HCL Technologies's top competitors. CTS is headquartered in Teaneck, New Jersey, and was founded in 1994. Like HCL Technologies, CTS also operates in the IT Services field. CTS generates $148 \%$ the revenue of HCL Technologies.

- TCS has been one of HCL Technologies's top competitors. TCS's headquarters is in Mumbai, Maharashtra, and was founded in 1968. TCS is in the Business Support Services industry. TCS generates $268 \%$ of HCL Technologies's revenue.

\section{SUGGESTION :}

- HCL has a substantial number of channel accomplices however it isn't supporting and taking consideration every one of them similarly which brings about expanding dissatisfaction among new channel accomplices since it's impractical for organization to help every one of them similarly. Organization should make some positive move against it.

- They should give careful consideration towards checking of different parts of PC before end client conveyance. Else it tends towards malign of brand name in contrast with rivals.

- Need to expand customer care centre as the consumer base of HCL Info system is increasing with tremendously fast pace.

- Correct attention should be paid for add planning otherwise it may lead to problem for the dealer as well as for the company.

\section{CONCLUSION :}

Despite competition from other leading companies, HCL still maintained the standard of products and services which they provide to the world. HCL produce defence projects for Indian country. HCL also takes many steps for social and environmental developments. The products and services of HCL technologies are analysed as per the guidelines of case analysis methodology as given in standard 
Company analysis methodology. The efforts of HCL in maintaining the quality of its products and services are discussed and many possible improvements are suggested.

\section{REFERENCES :}

[1] Aithal, P. S. (2017). Industry Analysis - The First Step in Business Management Scholarly Research. International Journal of Case Studies in Business, IT and Education (IJCSBE), 2(1), 113. DOI: http://dx.doi.org/10.5281/zenodo.810347.

[2] Aithal, P. S., (2017). Company Analysis - The Beginning Step for Scholarly Research. International Journal of Case Studies in Business, IT and Education (IJCSBE), 1(1), 1-18. DOI: http://dx.doi.org/10.5281/zenodo.573769.

[3] Jithin Raj, K. \& Krishna Prasad, K. (2018). A Critical Study on Business Strategies of 3i Infotech Ltd. International Journal of Case Studies in Business, IT and Education (IJCSBE), 2(1), 13-21. DOI: http://dx.doi.org/10.5281/zenodo. 1247319.

[4] Aithal, P. S. (2017). An Effective Method of Developing Business Case Studies based on Company Analysis, International Journal of Engineering Research and Modern Education (IJERME), 2(1), 16-27. DOI: http://dx.doi.org/10.5281/ZENODO.400579.

[5] Aithal Architha \& Aithal, P. S. (2018). How and Why Wharton Business School became World Topper - A Case Study on Organizational Quest for Excellence of First US Business School. International Journal of Application or Innovation in Engineering \& Management (IJAIEM), 7(1), 15-42. ISSN 2319 - 4847, DOI : http://doi.org/10.5281/zenodo.1164718.

[6] Keerthan R. \& Aithal, P. S. (2018). A 'Desi’ Multinational - A Case Study of Hindustan Unilever Limited. International Journal of Case Studies in Business, IT and Education (IJCSBE), 2(1), 112. DOI: http://dx.doi.org/10.5281/zenodo.1147365.

[7] Aithal P. S., Anil Kumar, Madhushree, \& Revathi R. (2018). Investigation of Business Strategies in Higher Education Service Model of Selected Private Universities in India. International Journal of Computational Research and Development (IJCRD), 3(1), 77-100. DOI : http://doi.org/10.5281/zenodo.1209910.

[8] Madhushree, Revathi R. Anil Kumar, \& Aithal, P. S. (May 2018). Business Strategy of Top Indian IT Company: MindTree. International Journal of Case Studies in Business, IT, and Education (IJCSBE), 2(1), 22-36. DOI: http://dx.doi.org/10.5281/zenodo.1249871.

[9] Aithal, P. S. (2017). Factor Analysis based on ABCD Framework on Recently Announced New Research Indices, International Journal of Management, Technology, and Social Sciences (IJMTS), 1(1), 82-94. DOI: http://dx.doi.org/10.5281/zenodo.584105.

[10] Aithal, P. S., (2017). ABCD Analysis as Research Methodology in Company Case Studies. International Journal of Management, Technology, and Social Sciences (IJMTS), 2(2), 40-54. DOI: http://dx.doi.org/10.5281/zenodo.891621.

[11] Aithal,P. S. \& Suresh Kumar, P.M. (2016). Innovations in Private Universities : A Case of Srinivas University. International Journal of Management, IT and Engineering (IJMIE), 6(1), 250-264. DOI : http://doi.org/10.5281/zenodo.161151.

[12] Aithal, P. S. \& Suresh Kumar, P. M. (2017). Challenges and Opportunities for Research\& Publications in Higher Education. International Journal of Scientific Research and Modern Education (IJSRME), 2(1), 42-49. DOI: http://dx.doi.org/10.5281/ZENODO.400619.

[13] Paul P.K., Aithal, P. S., Bhuimali A., \& Krishna Raj, (August 2017). National Telecommunication and Information Administration (NTIA): The Promoter of Digital Humanities and Sociology-A Case Study, International Journal of Scientific Research in Physics and Applied Sciences, 5(4), 24-27. DOI: http://doi.org/10.5281/zenodo.888201. 
[14] Sridhar Acharya, Aithal, P. S., (2017). Opportunities and Challenges of Producing Solar Energy in Every Indian Home - A case Study. International Journal of Case Studies in Business, IT and Education (IJCSBE), 1(2), 114-119. DOI: http://dx.doi.org/10.5281/zenodo.1133921.

[15] Aithal, P. S., (2016). Study on ABCD Analysis Technique for Business Models, business strategies, Operating Concepts \& Business Systems, International Journal in Management and Social Science, 4(1), 98-115. DOI : http://doi.org/10.5281/zenodo.161137.

[16] Aithal, P. S., Shailashree, V. T., Suresh Kumar, P. M. (2015). A New ABCD Technique to Analyze Business Models \& Concepts. International Journal of Management, IT and Engineering (IJMIE), 5(4), 409 - 423.DOI : http://doi.org/10.5281/zenodo.61652.

[17] Aithal, P. S. Suresh Kumar, P. M. (2015). Applying SWOC Analysis to an Institution of Higher Education.International Journal of Management, IT and Engineering (IJMIE), 5(7), 231-247. DOI : http://doi.org/10.5281/zenodo.163425.

[18] Laveena D’Mello. (2017). NGO’s Intervention to Bring Change in the Society- A Case Study of 'SIRRA'. International Journal of Case Studies in Business, IT and Education (IJCSBE), 1(1), 19-26. DOI: http://dx.doi.org/10.5281/zenodo.580084.

[19] Sneha, M. S. \& Krishna Prasad, K. (2018). Analysis of Business Strategies of Salesforce.com Inc. International Journal of Case Studies in Business, IT and Education (IJCSBE), 2(1), 37-44. DOI: http://dx.doi.org/10.5281/zenodo.1252028.

[20] Yin, R. K. (1992). The case study method as a tool for doing evaluation. Current Sociology, 40(1), 121-137.

[21] Stake, R. E. (1978). The Case Study Method in Social Inquiry 1. Educational researcher, 7(2), 58.

[22] Flyvbjerg, B. (2006). Five misunderstandings about case-study research. Qualitative inquiry, 12(2), 219-245.

[23] Gerring, J. (2004). What is a case study and what is it good for?. American political science review, 98(2), 341-354.

[24] Runeson, P. \& Höst, M. (2009). Guidelines for conducting and reporting case study research in software engineering. Empirical software engineering, 14(2), 131.

[25] Bowen, G. A. (2009). Document analysis as a qualitative research method. Qualitative research journal, 9(2), 27-40.

[26] Noor, K. B. M. (2008). Case study: A strategic research methodology. American journal of applied sciences, 5(11), 1602-1604.

[27] About Us | HCL Technologies. (n.d.). Retrieved from https://www.hcltech.com/about-us

[28] HCL Technologies. (2018, May 23). Retrieved from https://en.wikipedia.org/wiki/HCL_Technologies

[29] Autonomics And Orchestration | HCL Technologies. (n.d.). Retrieved from https://www.hcltech.com/autonomics-and-orchestration

[30] Cybersecurity \& GRC Services | HCL Technologies. (n.d.). Retrieved from https://www.hcltech.com/cyber-security-grc-services

[31] Business Services (BSERV) | HCL Technologies. (n.d.). Retrieved from https://www.hcltech.com/business-process-outsourcing-bpo

[32] Engineering and R\&D Services | HCL Technologies. (n.d.). Retrieved from https://www.hcltech.com/engineering-rd-services

[33] Systems Integration | HCL Technologies. (n.d.). Retrieved from https://www.hcltech.com/systems-integration 
International Journal of Case Studies in Business, IT and

[34] Infrastructure Management Services | HCL Technologies. (n.d.). Retrieved from https://www.hcltech.com/it-infrastructure-management-services

[35] HCL Technologies. (2018, May 23). Retrieved from https://en.wikipedia.org/wiki/HCL_Technologies

[36] Thalla, V. (2013, December 04). Hcl. Retrieved from https://www.slideshare.net/vishalkeshav/hcl-28909419

[37] Business Standard. (n.d.). HCL Technologies Ltd. Retrieved from http://www.businessstandard.com/company/hcl-technologies-5656/peer-comparisons/competition/9

[38] Socially Responsible Business | HCL Technologies. (n.d.). Retrieved from https://www.hcltech.com/socially-responsible-business

[39] Training Hiring Programs | HCL Technologies. (n.d.). Retrieved from https://www.hcltech.com/careers/training-hiring-programs 